\title{
КУМАРИНЫ, ФЛАВОНОИДЫ И ЛИГНАНЫ ПЯТИ ВИДОВ РАСТЕНИЙ РОДА HAPLOPHYLLUM A. JUSS
}

\author{
(С) Э.Х. Ботиров ${ }^{*}$, М.П. Юлдашев 2 , А.Д. Маткаримов 2 , В.М. Маликов ${ }^{2}$ \\ ${ }^{1}$ Сургутский государственный университет, ул. Ленина, 1, Сургут, 628412 \\ (Росcuя), e-mail: botirov-nepi@mail.ru \\ ${ }^{2}$ Институт химии растительных веществ им. акад. С.Ю. Юнусова, АН РУз, \\ ул. Мирзо Улугбека, 77, Ташкент, 700170 (Республика Узбекистан)
}

\begin{abstract}
Проведен обзор материалов по исследованию кумаринов, флавоноидов и лигнанов пяти видов растений рода Haplophyllum (семейство Rutaceae). Установлено, что каждый изученный вид растений продуцирует кумарины определенного структурного типа, а качественный и количественный составы кумаринов меняются в зависимости от экологогеографических, почвенно-климатических условий, а также периода вегетации и органа растения. Выявлены некоторые структурные особенности и методы установления и обнаружения кумаринов на ТСХ. Предложена возможная схема биогенеза кумаринов растения H. obtusifolium Ledeb. На основании анализа полученных данных и с учетом схемы биогенеза кумаринов для обтусина, обтусифола и тусифолидиола предложена альтернативная структура.

Ключевые слова: Haplophyllum A. Juss., кумарины, флавоноиды и лигнаны, биогенез, строение.
\end{abstract}

Растения рода Haplophyllum A. Juss (семейство Rutaceae) в мировом масштабе представлены примерно 70 видами, которые распространены от Средиземноморья до Западной Сибири [1-3]. На территории стран Центральной Азии произрастают 23 вида Haplophyllum [3, 4]. Различные виды Haplophyllum издавна применяются в народной медицине для лечения кожных, нервных заболеваний, а также в качестве противоядия при отравлениях, жаропонижающего, болеутоляющего, слабительного средства, при заболеваниях желудка и селезенки [3-5]. Экстракты некоторых видов проявляют противоопухолевую и цитотоксическую активность [3]. Поэтому они привлекают внимание исследователей в качестве потенциальных источников биологически активных веществ. Растения этого рода являются типичными алкалоидоносами и содержат хинолиновые, фуранохинолиновые алкалоиды и амиды [3, 6, 7]. Исследования показали, что растения рода Haplophyllum являются также перспективными и богатыми источниками кумаринов, флавоноидов и лигнанов [3, 7-13].

Нами фитохимическому исследованию на наличие кумаринов, флавоноидов и лигнанов подвергнуты 5 видов Haplophyllum: H. perforatum Kar. et Kir., H. obtusifolium Ledeb, H. davuricum (L.) G. Do., H. latifolium Kar. et Kir. и H. versicolor Fisch. et Mey, из которых выделено 26 кумаринов, 9 флавоноидов и 4 лигнана (табл. 1). Новыми оказались 17 кумаринов, 8 флавоноидов и 2 лигнана [14-20].

Кумарины обнаружены в трех из пяти изученных нами видов - H. perforatum, H. obtusifolium, H. davuricum. В литературе имеется сообщение о наличии кумарина версиколина в растении H. versicolor [12], однако нами при тщательном изучении надземной части этого растения, собранного на территории Кара-

Ботиров Эркин Хожиакбарович - заведующий

кафедрой химии, професcop, e-mail: botirov-nepi@mail.ru Юлдашев Малик Патахович - бывший ведущий научный сотрудник лаборатории химии кумаринов и терпеноидов

Маткаримов Анатолий Джуманиязович - бывший научный сотрудник лаборатории химии кумаринов и терпеноидов

Маликов Васит Маликович - ведущий научный сотрудник лаборатории химии кумаринов и терпеноидов калпакии, кумарины не обнаружены. Анализ состава и структуры выделенных веществ показывает, что каждый изученный нами вид продуцирует кумарины определенного структурного типа. Например, $H$. perforatum содержит производные 6,7диоксикумарина (соединения 1, 15-20) [17], тогда как H. davuricum продуцирует, в основном, вещества, относящиеся к производным 7-окси- (соедине-

\footnotetext{
* Автор, с которым следует вести переписку.
} 
ния 21, 23-25) и 5,7-диоксикумарина (соединения 22, 26) $[14,15,18]$. Из надземной части H. obtusifolium выделены производные 6,7-диокси- (соединения 1-6) и 6,7,8-триоксикумарина (соединения 7-12, 14) [16]. Из корней этого растения выделено также производное 7-оксикумарина обтусифолин, содержащий две пренильные группы [19]. Скополетин обнаружен во всех трех указанных видах, в которых обнаружены кумарины. Следует отметить, что среди изученных видов только H. obtusifolium продуцирует производные 6,7,8-триоксикумарина, которые могут служить хемотаксономическим признаком на видовом уровне.

Из растений рода Haplophyllum нами выделены 13 кумариновых гликозидов (соединения 5, 6, 14, 15-20, 23-26), в том числе 6 монозидов, 6 биозидов и один триозид. Все они являются гликозидами умбеллиферона (7-гидроксикумарина), скополетина (6-метокси-7-гидроксикумарина) и фраксетина (6-метокси7,8-дигидроксикумарина). В состав углеводных цепей вышеуказанных гликозидов входят D-глюкоза и L-рамноза. Составной частью биозидов (соединения 16-19, 24, 25) являются рутиноза [6-O- $(\alpha-\mathrm{L}-$ рамнопиранозил)-D-глюкоза] и неогесперидоза [2-O-( $\alpha$-L-рамнопиранозил)-D-глюкоза], а триозида хаплоперозида Е (20) - 2-рамнозилрутиноза.

Обнаружены 5 этерифицированных гликозидов (соединения 6, 17, 18, 24, 25), ацильные группы которых локализованы в углеводной части и представлены остатками уксусной, $n$-кумаровой и феруловой кислот [20]. Кроме того, из H. davuricum выделен первый кумарин - C-гликозид даурозид Д (6-C- $\beta$-Dглюкопиранозил-5,7-дигидроксикумарин, 26) [15].

Таблица 1. Кумарины, флавоноиды и лигнаны, выделенные из изученных видов Haplophyllum

\begin{tabular}{|c|c|c|c|}
\hline \multirow{2}{*}{ Вид растения } & \multicolumn{3}{|c|}{ Выделенные соединения } \\
\hline & кумарины & флавоноиды & лигнаны \\
\hline $\begin{array}{l}\text { H. perforatum Kar } \\
\text { et Kir }\end{array}$ & $\begin{array}{c}\text { скополетин (1), скополин (15), } \\
\text { хаплоперозид А (16), хаплоперозид В } \\
(17), \text { хаплоперозид С (18), хаплоперо- } \\
\text { зид Д (19), хаплоперозид Е (20) }\end{array}$ & 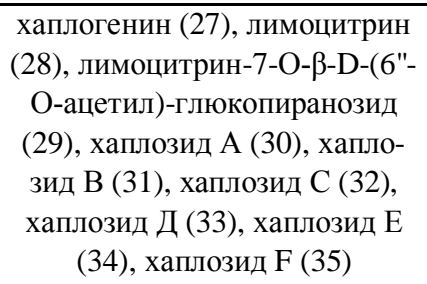 & эудесмин (36) \\
\hline $\begin{array}{l}\text { H. obtusifolium } \\
\text { Ledeb }\end{array}$ & $\begin{array}{c}\text { скополетин (1), 6-метокси-7- }, \gamma-д и- \\
\text { метилаллилоксикумарин (2), обтусинол } \\
(3), \text { обтусинин (4), обтусозид (5), фе- } \\
\text { рулоил- скополин (6) фраксетин (7), } \\
\text { капенсин (8), обтусицин (9), обтуси- } \\
\text { пренин (10), обтусипренол (11), обту- } \\
\text { сидин (12), обтусифолин (13), фраксе- } \\
\text { тин-7-О-глюкозид (14) }\end{array}$ & хаплозид В (31) & $\begin{array}{l}\text { юстицидин В } \\
\text { (34), дифил- } \\
\text { лин (35) }\end{array}$ \\
\hline $\begin{array}{l}\text { H. davuricum (L.) } \\
\text { G.Don }\end{array}$ & $\begin{array}{c}\text { умбеллиферон (21), скополетин, 5,7- } \\
\text { диоксикумарин (22), скиммин (23), } \\
\text { даурозид А (24), даурозид В (25), } \\
\text { даурозид Д (26) }\end{array}$ & $\begin{array}{l}\text { хаплогенин (27), хаплозид В } \\
\text { хаплозид Д (33), }\end{array}$ & $\begin{array}{l}\text { юстицидин В, } \\
\text { дифиллин } \\
\text { дауринол (37) }\end{array}$ \\
\hline $\begin{array}{l}\text { H. latifolium Kar } \\
\text { et Kir }\end{array}$ & 皮 & $\begin{array}{c}\text { хаплогенин (27), хаплозид В } \\
\text { (31), хаплозид Д (33) }\end{array}$ & - \\
\hline $\begin{array}{l}\text { H. versicolor } \\
\text { Fisch.et Mey }\end{array}$ & - & ( & $\begin{array}{c}\text { версикозид } \\
(38) \\
\end{array}$ \\
\hline
\end{tabular}

Данные, полученные нами и другими исследователями, показывают, что качественный и количественный составы кумаринов изученных видов растений сильно меняются в зависимости от экологогеографических, почвенно-климатических условий, а также периода вегетации и органа растения. Одни и те же виды данного рода, произрастающие в различных географических зонах, могут содержать разные по каче-

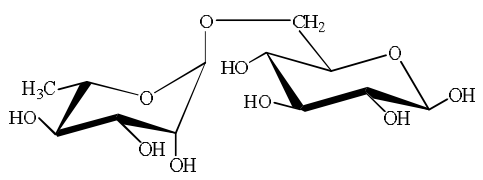

Рутиноза

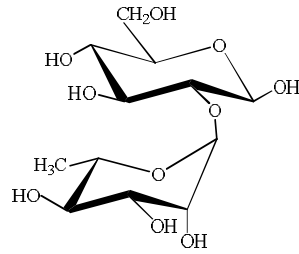

Неогесперидоза ственному и количественному составу кумарины. Например, из H. obtusifolium, произрастающей на Устюрте, нами выделены кумарины, приведенные в таблице 1, в то время как это же растение, собранное на территории Туркмении, содержит совершенно другие кумарины (обтусин, обтусифол, тусифолидиол, тусифолинол, хаптусинол) [9-11,21].

На примере H. obtusifolium показана вариабельность качественного и количественного состава кумаринов надземной части в зависимости от периода вегетации растения (табл. 2). Так, из надземной части 
растения, собранного в период цветения, выделены 6-метокси-7- $\gamma, \gamma$-диметилаллилоксикумарин (2), капенсин (8), обтусинол (3), обтусинин (4), фраксетин (7), обтусицин (9), обтусозид (5), а также лигнаны юстицидин В (34) и дифиллин (35), тогда как из растения, собранного в период плодоношения из этого же места произрастания, выделены 6-метокси-7-диметилааллилоксикумарин (2), капенсин (8), скополетин (1), фраксетин (7), обтусицин (9), обусинин (4), обтусозид (5), обтусидин (12), обтусипренин (10), ферулоилскополин (6), обтусипренол (11), фраксетин-7-О-глюкозид (13). При этом отмечено интенсивное накопление в конечной стадии вегетации растения кумаринов, содержащих изопреноидные земестители. Из корней данного растения выделены кумарин обтусифолин и лигнан дифиллин [19].

Для обнаружения кумаринов на пластинках ТСX широко используют их способность флуоресцировать при облучении УФ-лучами. Нами установлено, что в отличие от производных 7-окси-, 5,7-диокси- и 6,7-диоксикумарина производные 6,7,8-триоксикумарина с незамещенной гидроксильной группой в положениях C-7 и С-8 (обтусидин, обтусипренин, обтусипренол) на пластинках силуфоль не флуоресцируют в УФ-свете, а обнаруживаются в виде темно-коричневых пятен.

Из H. obtusifolium выделены кумарины, имеющие пренильные $\left[\left(\mathrm{CH}_{3}\right)_{2} \mathrm{C}=\mathrm{CH}-\mathrm{CH}_{2}-\right]$ группы, а также их различные структурные модификации. Вышеуказанные заместители связаны с кумариновым ядром как непосредственно C-C-связью, так и через кислородный атом. Природа связи может быть установлена по результатам кислотного гидролиза, данным ЯМР и масс-спектров. В масс-спектрах О-аллиловых эфиров кумаринов пик молекулярного иона имеет низкую интенсивность, тогда как в спектрах соответствующих С-алкильных аналогов пик молекулярного иона часто является максимальным. Так, в спектрах капенсина (8) и обтусипренина (10) относительная интенсивность пиков молекулярных ионов составляют 1,2 и $100 \%$ соответственно [16].

В ЯМР-спектрах кумаринов сигналы протонов метиленовой группы пренильного остатка, связанного с кумариновым ядром через кислород (соединения $2,3,8,9)$, проявляются в более слабом поле $(4,62-$ 4,86 м.д.) по сравнению с сигналом протонов $\mathrm{CH}_{2}$-группы в спектрах $\mathrm{C}$-пренилкумаринов (кумарины 10 , 11) $(3,20-3,60$ м.д.) [16].

Кумарины обтусидин (12) и обтусифолин (13) содержат необычную $\alpha, \alpha$-диметилаллильную группу в положении С-3 кумаринового ядра. Взаимное расположение $\alpha, \alpha$-диметилаллильной и $\gamma$-метил- $\alpha, \gamma-$ бутадиенильной групп при С-3 и С-8, в молекуле обтусифолина ранее нами было предложено на основании биогенетических соображений. В результате изучения кумарина клаусарина, содержащего две $\alpha, \alpha-$ диметилаллильной группы в положениях С-3 и С-8, методом двумерной ЯМР-спектроскопии показано, что значения химических сдвигов сигналов ядер ${ }^{1} \mathrm{H}$ и ${ }^{13} \mathrm{C}$ вышеуказанного заместителя зависят от его месторасположения. Так, в спектре ${ }^{13} \mathrm{C}$ ЯМР клаусарина сигналы атомов углерода-13 $\alpha, \alpha$-диметилаллильной группы при С-3 проявляются при 40,18, 145,63, 111,90, 26,19 м.д., тогда как сигналы ядер ${ }^{13} \mathrm{C}$ этой же группы, расположенной при С-8, наблюдаются при 40,88, 150,12, 107,94, 29,50 м.д. [22]. Сравнение значений химических сдвигов сигналов углерода-13 $\alpha, \alpha$-диметилаллильной группы в спектре ${ }^{13} \mathrm{C}$ ЯМР обтусифолина [40,3 (C-1), 145,6 (C-2), 112,2 (C-3), 26,1 (C-4, 5) м.д.] с таковыми клаусарина подтверждает предложенную для первого кумарина структуру 13.

Таблица 2. Содержание кумаринов H. obtusifolium в различные периоды вегетации растения

\begin{tabular}{l|c|c}
\hline \multicolumn{1}{c|}{ Кумарины } & Выход кумаринов (в \% от веса воздушно-сухого растения) \\
\cline { 2 - 3 } & Период цветения & Период плодоношения \\
\hline Скополетин (1) & - & $\mathrm{c}$ \\
6-Метокси-7- $\gamma, \gamma$-диметилал-лилоксикумарин (2) & 0,023 & - \\
Обтусинол (3) & $\mathrm{c}$ & 0,19 \\
Обусинин (4) & 0,08 & 0,27 \\
Обтусозид (5) & 0,054 & 0,005 \\
Ферулоилскополин (6) & - & 0,14 \\
Фраксетин (7) & 0,018 & 0,17 \\
Капенсин (8) & 0,84 & 0,26 \\
Обтусицин (9) & 0,025 & 0,023 \\
Обтусипренин (10) & - & 0,025 \\
Обтусипренол (11) & - & 0,013 \\
Обтусидин (12) & - & 0,006 \\
Фраксетин-7-О-глюкозид (13) & - & . \\
\hline
\end{tabular}

Примечание: с - следовые количества $(<0,004 \%)$. 


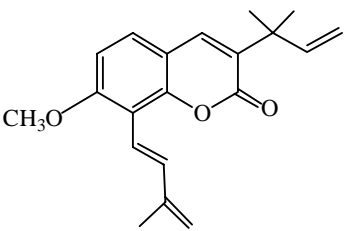

Обтусифолин (13)

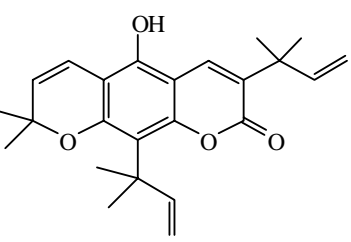

Клаусарин

В спектрах кумаринов обтусинола (3) и обтусицина (9), содержащих 3-гидроксиметил2-бутенильного [- $\left.\mathrm{CH}_{2}-\mathrm{CH}=\left(\mathrm{CH}_{3}\right) \mathrm{CH}_{2} \mathrm{OH}\right]$ заместителя, значение химического сдвига сигналов углерода-13 винилметильной группы позволяет определить конфигурацию двойной связи [23]. Сигналы ядер углерода винилметильной группы в спектрах ${ }^{13} \mathrm{C}$ ЯМР обтусицина и обтусинола резонируют при 21,3 и 14,0 м.д. соответственно, что свидетельствует о Z- и Е-конфигурациях двойной связи в боковой цепи вышеуказанных кумаринов соответственно.

Строение обтусинола и обтусинина подтверждено синтезом, выполненным учеными Индии исходя из 6-метокси-7- $\gamma, \gamma$-диметилаллилоксикумарина [24].

Анализ структуры выделенных кумаринов позволяет предполагать, что, по-видимому, предшественником всех кумаринов H. obtusifolium является скополетин (1), из которого в результате гликозилирования, пренилирования и последующих реакций ацилирования, окисления и иных образуются другие 6,7ди-замещенные кумарины (рис. 1).

Включение изопентенильного радикала (пренилирование) осуществляется действием резо- нансностабилизированного аллильного катиона $\left[\left(\mathrm{CH}_{3}\right)_{2} \mathrm{C}=\mathrm{CH}-\mathrm{CH}_{2}{ }^{+}\right]$, образующегося из $\gamma, \gamma$-диметилаллилпирофосфата на 7-гидроксикумарины $[25,26]$. Ионизация 7-гидроксикумаринов ведет к феноксидиону, которые, взаимодействуя с вышеуказанным аллильным катионом, превращаются в 7-О-изопентенилкумарины. Локализация отрицательного заряда на атомах С-6 и С-8 создает благоприятные условия для синтеза соответствующих С-изопентенилкумаринов [25-27]. Доказана возможность образования фраксетина (7) в результате окисления скополетина in vivo [28]. Очевидно, фраксетин далее превращается в капенсин (8), обтусипренин (10), фраксетин-7-О-глюкозид (14) и другие кумарины, указанные на рисунке 1. Локализация отрицательного заряда на атоме C-6 фраксетина создает благоприятные условия для синтеза обтусипренина [16]. Установлено, что кумарины, содержащие $\alpha, \alpha$-диметилаллилную группу в положении С-3 синтезируются в растениях из 7-О-изопентенилкумаринов в результате трехкратной перегруппироки Кляйзена при низкой температуре с участием ферментов [25, 26]. Обтусидин (12) синтезируется из капенсина (8) в результате трехступенчатой перегруппировки Кляйзена (рис. 2) [25].

Эту реакцию мы осуществляли в лабораторных условиях [29]. Нами также проведена химическая корреляция обтусипренола (11) с обтусипренином (10). При окислении диацетилобтусипренина диоксидом селена в уксусном ангидриде получен триацетиообтусипренол, щелочной гидролиз которого привел к получению обтусипренола (11).

Как указано выше, из растения Haplophyllum obtusifolium, собранного на территории Туркмении, были выделены кумарины обтусин, обтусифол, тусифолидиол $[10,11,21]$, для которых предложены следующие структурные формулы:<smiles>[R]C1Oc2c(OC)cc3ccc(=O)oc3c2OC1[R]</smiles><smiles>[R][R]O[Na]</smiles>

Анализ структуры выделенных из Haplophyllum obtusifolium кумаринов и биогенетических путей их образования позволяет пересмотреть предложенные для обтусина, обтусифола и тусифолидиола строение. Следует отметить, что 7-О-пернильные производные фраксетина часто встречаются в растениях, тогда как 8-О-пренильные производные практически не обнаружены. Это, вероятно, связано с большей кислотностью и легкостью ионизации 7-ОН группы с образованием феноксид-иона, легко образующего 7-О-пренильные кумарины в результате взаимодействия с катионом $\left[\left(\mathrm{CH}_{3}\right)_{2} \mathrm{C}=\mathrm{CH}_{-} \mathrm{CH}_{2}^{+}\right][23,25]$. Очевидно, окисление 7-О-пренилированного кумарина капенсина (8) приводит к эпоксиду 8а, который в результате циклизации образует обтусифол. Далее дегидратация обтусифола приводит к обтусину, а окисление - к тусифолидиолу (рис. 3). Таким образом, вышеуказанные кумарины должны иметь строение, указанное на рисунке 3. 

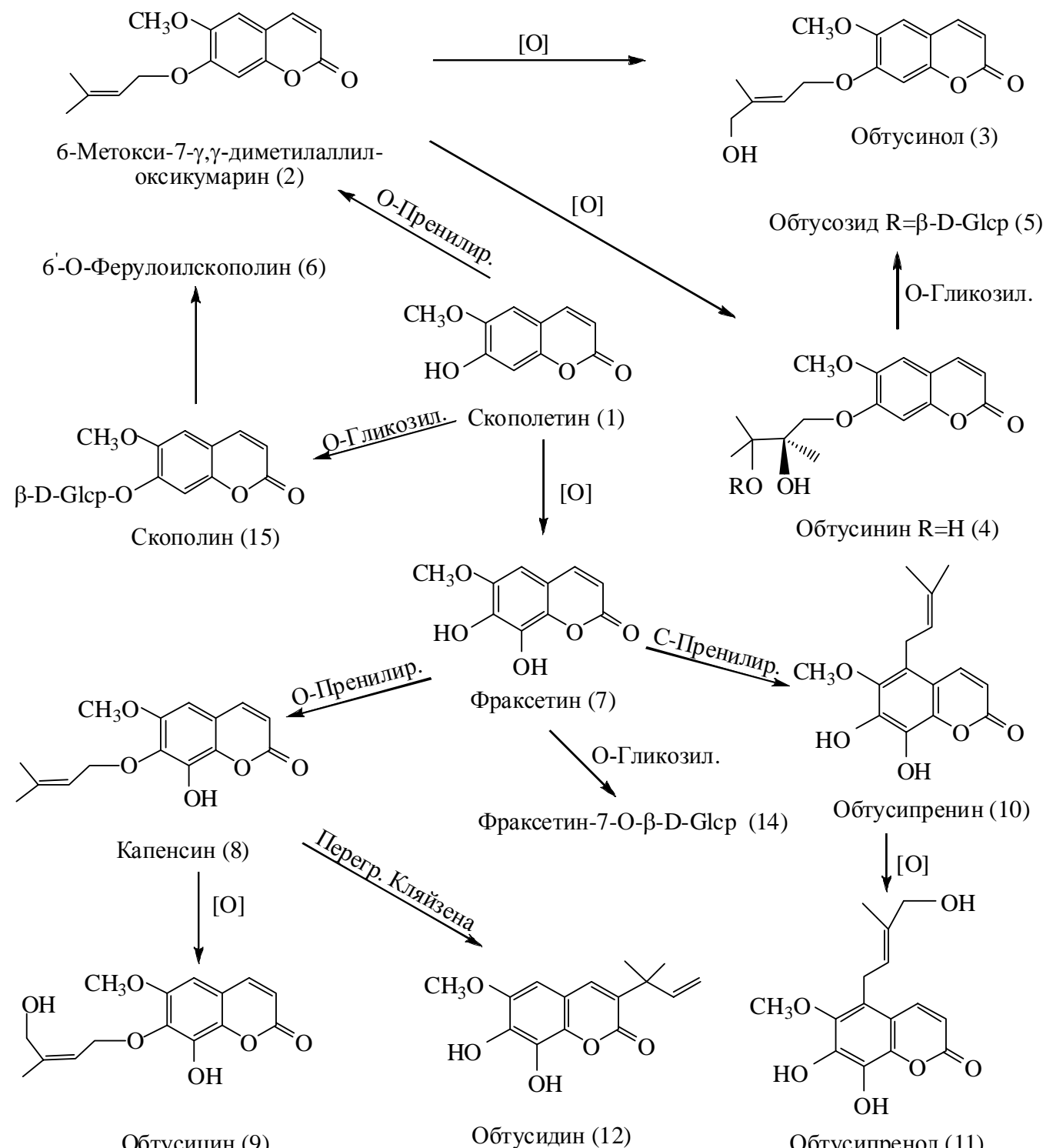

Рис. 1. Возможная схема биогенеза кумаринов H. obtusifolium Ledeb<smiles>C=CC(C)(C)C1(C)C(=O)C(O)=c2oc(=O)ccc2=C1C(=O)C(C)(C)C(C)(C)C(C)(C)C</smiles>

Капенсин (8)<smiles>C=CC(C)(C)c1cc2cc(OC)c(O)c(O)c2oc1=O</smiles>

Обтусидин (12)

Рис. 2. Схема биогенеза обтусидина из капенсина 


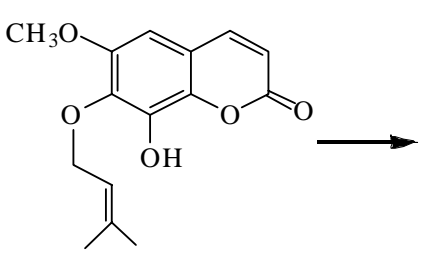

Капенсин (8)<smiles>COc1cc2ccc(=O)oc2c(O)c1OCC(=O)O</smiles>

Продукт окисления (8a)

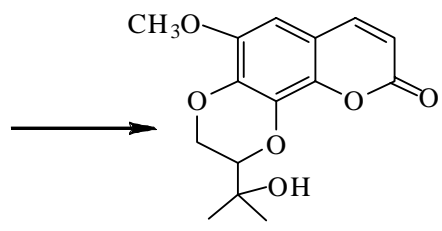

Обтусифол<smiles>C=C(C)C1COc2c(OC)cc3ccc(=O)oc3c2O1</smiles>

Обтусин

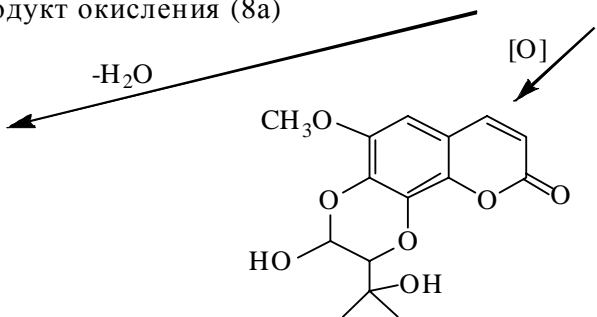

Тусифолидиол

Рис. 3. Биосинтез обтусифола, обтусина и тусифолидиола из капенсина

Выделение из Haplophyllum obtusifolium кумарина хаптусинола, содержащего 2-гидрокси-3метилбутокси-группу в положении 7 кумаринового ядра [11], и установление строения пурпуренола методом РСА [30] подтверждают наше предположение.

Из Haplophyllum perforatum выделены флавоноиды хаплогенин, лимоцитрин, а также их гликозиды и ацилгликозиды $[17,31-36]$. Хаплогенин оказался новым флавонолом и имеет строение 3-О-метилового эфира госсипетина (3,5,7,8,3,4-гексагидроксифлавона), а лимоцитрин - 3,8-ди-О-метиловый эфир госсипетина. Впоследствии гликозиды хаплогенина выделены Дж. Харборном из цветков Coronilla valentine [37]. Максимумы поглощения в УФ-спектрах производных госсипетина, в том числе и хаплогенина $(\lambda 262,279$, 386 нм) и лимоцитрина ( $\lambda 260,274 *, 341^{*}, 381$ нм), лежат в более длинноволновой области по сравнению с другими флавонолами, вследствие чего они имеют ярко-желтую окраску. Установлено, что эти флавоноиды служат веществами, привлекающими опылителей (указателями нектара) [37].

Из Haplophyllum perforatum выделены глюкозиды (соединение 31) и неогесперидозиды (соединения 34 и 35) хаплогенина и лимоцитрина, а также их ацетильные производные (соединения 29, 30, 32, 33), имеющие аналогичную углеводную часть и отличающиеся только природой агликона. Во всех гликозидах, выделенных из этого растения, углеводная часть присоединена к 7-ОН-группе агликона (хаплогенина или лимоцитрина), а ацетильная группа - к первичной спиртовой гидроксильной группе остатка D-глюкозы.<smiles>COc1cc2ccc(=O)oc2c(O)c1OCC(O)C(C)C</smiles>

Хаптусинол<smiles>COc1c2c(c3oc(=O)ccc3c1OC)OC(C(C)(C)O)CO2</smiles>

Пурпуренол<smiles>[R20]c1c(O)cc(O)c2c(=O)c(O)c(-c3ccc(O)c(OC)c3)oc12</smiles>

Хаплогенин $\quad \mathrm{R}=\mathrm{H}$

Лимоцитрин $\mathrm{R}=\mathrm{CH}_{3}$

Гликозиды хаплогенина и лимоцитрина легко можно различать по качественной реакции c $n$-бензохиноном (госсипетиновая проба) и по окраске на ТCX. Хаплогенин и его гликозиды дают положительную реакцию с $n$-бензохиноном, а на хроматограммах ТCX на силуфоле их желтое пятно через 30 40 мин приобретает зеленовато-синий оттенок, что связано окислением 5,8-диоксигруппировки кислородом воздуха. При снятии УФ-спектров в присутствии метилата натрия хаплогенин разлагается. Лимоцитрин и его гликозиды с замещенной гидроксильной (метоксильной) группой в положении С-8 при этом свою желтую окраску не меняют, не дают госсипетиновую пробу и при снятии УФ-спектров в щелочной среде устойчивы. 
Общим признаком всех изученных на содержание флавоноидов видов Haplophyllum является наличие в них производных госсипетина. Указанный факт свидетельствует о строгой специфичности ферментных систем, отвечающих за синтез гликозидов в растениях рассматриваемого рода.

Таким образом, особенности состава кумаринов и флавоноидов изученных видов Haplophyllum могут быть использованы для хемосистематики как отдельных видов, так и рода в целом.

Из пяти изученных видов растений рода Haplophyllum нами выделены лигнаны эудесмин (36), версикозид (38), юстицилин В (34), дифиллин (35), дауринол (37), причем последние три относятся к арилнафталиновым лигнанам. Строение арилнафталинового лигнана дауринола, установленное нами на основании химических превращений и спектральных данных, впоследствии подтверждено синтезом [38].

Растения рода Haplophyllum, как было указано выше, широко применяются в народной медицине, причем действующее начало большинства этих растений выясняется благодаря фитохимическим исследованиям. При фармакологических исследованиях обтусинин оказывал гипотензивное, а в более высоких дозах - выраженное успокаивающее действие на ЦНС [39].

Фраксетин, скополин, даурозид Д и обтусозид проявили спазмолитическую и гипотензивную активность [40]. Антиаритмическое свойство обнаружено у хаплоперозида А, который снимал аритмию, вызванную аконитином [40]. Фармакологическое изучение хаплозида С показало наличие у него гипоазотемического действия [36]. Особенно четко это прослеживалось в условиях эксперментальной почечной патологии, сопровождающейся довольно выраженным повышением содержания мочевины и остаточного азота. По своей активности хаплозида $\mathrm{C}$ незначительно уступает лекарственному средству леспенефрилу.

Хаплозид В проявляет гиполипидемическую, гипохолестеринемическую и антиоксидантную активность [41]. Дауринол показал выраженное антивирусное действие в отношении респираторносинтициального вируса [42]. Лигнан дифиллин обладает значительным цитотоксическим действием, превышающим активность лекарственного препарата меркаптопурин в 2 раза [43]. Дифиллин в дозе 0,05 мкг/мл избирательно и полностью подавляет синтез ДНК, юстицидин В проявляет ихтиотоксическую активность [44].

Умбеллиферон, скополетин, хаплоперозиды А и В в концентрации от 1 до 500 мкг/мл блокируют пентакетидный путь биосинтеза меланина у возбудителя вертициллезного вилта хлопчатника и могут быть использованы в качестве удобного инструмента в биохимических работах [45].

\section{Заключение}

Обобщены результаты исследований кумаринов, флавоноидов и лигнанов пяти видов растений рода Haplophyllum (семейство Rutaceae). Показано, что каждый изученный вид растений продуцирует кумарины определенного структурного типа, а качественный и количественный составы кумаринов меняются в зависимости от эколого-географических, почвенно-климатических условий, а также периода вегетации и органа растения. Одни и те же виды данного рода, произрастающие в различных географических зонах, содержат разные по качественному и количественному составу кумарины. Выявлены некоторые структурные особенности и методы установления строения и обнаружения кумаринов на ТСХ. Подтверждено ранее предложенное строение кумарина обтусифолина, представлена возможная схема биогенеза кумаринов растения H. obtusifolium Ledeb. На основании анализа полученных данных для обтусина, обтусифола, и тусифолидиола предложена альтернативная структура.

\section{Список литературы}

1. Willis J.C. A Dictionary of the flowering plants and ferns. Seventh edition. Cambridge, $1966.519 \mathrm{p}$.

2. Род Haplophyllum. Описание таксона [Электронный pecypc]. URL: http://www.plantarium.ru/page/view/item/44438.html

3. Растительные ресурсы СССР: Цветковые растения, их химический состав, использование. Семейства Rutaceae-Elaeagnaceae. Л., 1988. С. 10-15.

4. Халматов Х.Х. Дикорастущие лекарственные растения Узбекистана. Ташкент, 1964. 134 с.

5. Маркова Л.П., Беленовская Л.М., Надежина Т.П., Синицкий В.С. Дикорастущие полезные растения флоры Монгольской Народной Республики. Л., 1985. С. 78-79.

6. Бессонова И.А., Юнусов С.Ю. Хинолиновые алкалоиды Нарlophyllum // Химия природных соединений. 1977. №3. С. 303-324. 
7. Kholid S.A., Waterman P.G. Alkaloid, lignan and flavonoid constituents of Haplophyllum tuberculatum from Sudan // Planta Med. 1981. Vol. 43. Pp. 148-152.

8. Ulubelen A., Öztürk M. Alkaloids, coumarins and lignans from Haplophyllum species // Rec. Nat. Prod. 2008. Vol. 2. N3. Pp. 54-69.

9. Абышев А.З., Гашимов Н.Ф. О строении обтусифола // Химия природных соединений. 1979. №3. С. 401-403.

10. Абышев А.З., Гашимов Н.Ф. Обтусин - новый кумарин из Haplophyllum obtusifolium // Химия природных соединений. 1979. №3. С. 403-404.

11. Абышев А.З., Гашимов Н.Ф. Хаптусинол - новый кумарин из Haplophyllum obtusifolium // Химия природных соединений. 1979. №6. С. 845.

12. Gashimov N.F., Abyshev A.Z., Kagramanov A.A., Rozhkova L.I. Versicolin - A new coumarin from Haplophyllum versicolor // Chemistry of Natural Compounds. 1979. Vol. 15. N1. P. 71.

13. Parhoodeh P., Rahmani M., Mohd Hashim N., Sukari M.A., Gwendoline E., Lian Ch. Lignans and Other Constituents from Aerial Parts of Haplophyllum Villosum // Molecules. 2011. Vol. 16. Pp. 2268-2273.

14. Batirov E.Kh., Matkarimov A.D., Batsuren D., Malikov V.M. New coumarins and lignans from Haplophyllum obtusifolium and H.dauricum // Proc. first Inter. conf. Chem. and biotechnol. biol. active natur. prod. Varna, 1981. Vol. 3(1). Pp. 120-123

15. Вдовин А.Д., Батсурэн Д., Батиров Э.Х., Ягудаев М.Р., Маликов В.М. Спектры ЯМР ${ }^{1} \mathrm{H}$ и ${ }^{13} \mathrm{C}$ и строение нового кумарин-С-гликозида - даурозида Д из Haplophyllum dauricum // Химия природных соединений. 1983. №4. C. 441-445.

16. Маткаримов А.Д. Изучение кумаринов Haplophyllum obtusifolium Ledeb : автореф. дис. ... канд. хим. наук. Ташкент, 1985. $23 \mathrm{c}$.

17. Юлдашев М.П. Кумариновые и флавоноловые гликозиды Haplophyllum perforatum (М.В.) Kar et Kir. и Ferula varia (Schrenk) Trautv. : автореф. дис. ... канд. хим. наук. Ташкент, 1988. 21 с.

18. Батсурэн Д., Батиров Э.Х., Маликов В.М., Ягудаев М.Р. Строение даурозидов А и В - новых ацилированных кумариновых гликозидов из Нарlophyllum dauricum // Химия природных соединений. 1983. №2. С. 142-147.

19. Бессонова И.А., Батиров Э.Х., Ягудаев М.Р. Обтусифолин - новый кумарин из корней Haplophyllum obtusifolium // Химия природных соединений. 1988. №2. С. 187-189.

20. Батиров Э.Х., Юлдашев М.П., Маликов В.М. Фенолгликозиды кумаринового ряда // Химия природных соединений. 1990. №5. С. 577-592.

21. Абышев А.З., Змейков В.П., Сидорова И.П. Спектры ЯМР ${ }^{13}$ С и строение некоторых производных кумарина // Химия природных соединений. 1983. №3. С. 301-306.

22. Juichi M., Takemura Y., Okano M., Fukamiya N., Ito Ch., Furukawa H. Structure of bisclausarin, a new bicoumarin from Citrus plants // Heterocycles. 1991. Vol. 32. Pp. 1189-1191.

23. Breitmaier E.W. Voelter ${ }^{13}$ C NMR spectroscopy. New York: Verlag Chem., 1978. 912 p.

24. Ahluwalia V.K., Khanna M., Singh R.P. Syntesis of obtusinin and 7-(3'-htdroxymethoxybut-2'-enyloxy)-6-methoxy2H-1-benzopyran-2-one // Monatsh. Chem. 1982. Vol. 113. Pp. 197-200.

25. Grey A.L., Waterman P.G. Coumarins in the Rutaceae. // Phytochemistry. 1978. Vol. 17. Pp. 845-864.

26. Murray R.D.H, Mendez J., Brown S.A. The natural coumarins. New York, 1982. 648 p.

27. Murray R.D.H. Coumarins. Reviewing the literature published between mid-1980 and mid-1988 // Natur. Prod. Reports. 1989. Vol. 6. Pp. 591-624.

28. Brown S.A., March R.E., Rivett D.E.A., Thompson H.J. Intermediates in the formation of puberulin by Agathosma puberula // Phytochemistry. 1988. Vol. 27. Pp.391-395

29. Маткаримов А.Д. Батиров Э.Х., Маликов В.М., Сейтмуратов Е. Строение обтусидина и обтусипренина // Химия природных соединений. 1982. №2. С. 173-176.

30. Debenedetti S.L., Nadinic E.L., Coussio J.D., De Kimpe N., Dupon J.F., Declercq J.P. Purpurenol, a highly oxygenated coumarin from Pterocaulon purpurascens // Phytochemistry. 1991. Vol. 30. N8. Pp. 2757-2758.

31. Батиров Э.Х., Маликов В.М. Хаплозид А - новый ацилированный флавоноловый гликозид из Haplophyllum perforatum // Химия природных соединений. 1980. №3. С. 330-334.

32. Батиров Э.Х. Маликов В.М., Мирзаматов Р.Т. Хаплогенин-7-О-глюкозид из Наplophyllum perforatum // Химия природных соединений. 1980. №4. С. 836.

33. Батиров Э.Х., Маликов В. М., Перельсон М.Е. Строение ацилированного флавонолового гликозида хаплозида D // Химия природных соединений 1981. №3. С. 304-307.

34. Юлдашев М.П., Батиров Э.Х., Маликов В.М. Флавоноиды Haplophyllum perforatum. Новые гликозиды лимоцитрина // Химия природных соединений. 1985. №2. С. 192-196.

35. Юлдашев М.П., Батиров Э.Х., Маликов В.М. Флавоноиды Haplphyllum perforatum. Строение хаплозида F // Химия природных соединений. 1985. №2. С. 269.

36. Батиров Э.Х., Юлдашев М.П., Хушбактова 3.А., Сыров В.Н., Маликов В.М. Флавоноиды Haplophyllum perforatum. Строение и гипоазотемическая активность хаплозида С // Химия природных соединений. 1987. №1. C. 66-70.

37. Harborne J.B. Two gossypetin methyl ethers as ultraviolet pattering guids in the flowers of Coronilla valentina // Phytochemistry. 1981. Vol. 20. Pp. 1117-1119.

38. Anastas P.T., Stevenson R. Synthesis of Natural Lignan Arylnaphthalene Lactones, Daurinol and Retrochinensin // J. Nat. Prod. 1991. Vol. 54. N6. Pp. 1687-1691. 
39. Аминов С.Д., Вахабов А.А., Султанов М.Б. К фармакологии обтусинина // Медицинский журнал Узбекистана. 1982. №6. С. 52-54.

40. Аминов С.Д., Вахабов А.А. К фармакологии некоторых кумаринов из растения // Доклады АН УзССР. 1985. №8. C. 44-45.

41. Хушбактова 3.А., Сыров В.Н., Батиров Э.Х. Влияние флавоноидов на течение гиперлипидемий и атеросклероза в эксперименте // Химико-фармацевтический журнал. 1991. Т. 25. №4. С. 53-57.

42. Юлдашев М.П., Батиров Э.Х., Бабеков А.У., Юсупова С.М., Маматхонов А.У. Противовирусная активность некоторых флавоноидов, кумаринов и лигнанов // Наука, образование, техника. 1999. №2. С. 84-86.

43. Gonzalez A.G., Darvis V., Alonso G. Cytostatic lignan isolated from Haplophyllum hispanicum // Planta Med. 1979. Vol. 36. Pp. 200-203.

44. Inamori Y., Kubo M., Tsujibo H. et all. The biological activities of podophyllotoxin compounds // Chem Pharm. Bull. 1986. Vol. 34. Pp. 3928-3932.

45. Тен Л.Н., Степаниченко Н.Н., Мухамеджанов С.З., Асланов Х.А. Влияние кумаринов на биосинтез меланина гриба Verticillium dahliae // Химия природных соединений. 1987. №5. С. 772-773.

Поступило в редакичию 5 февраля 2014 г.

Botirov E.Kh. ${ }^{{ }^{*}}$, Yuldashev M.P. ${ }^{2}$, Matkarimov A.Dj. ${ }^{2}$, Malikov V.M. ${ }^{2}$ COUMARINS, FLAVONOIDS AND LIGNANS FIVE SPECIES OF PLANTS OF THE GENUS HAPLOPHYLLUM A. JUSS

${ }^{1}$ Surgut State University, ul. Lenina, 1, Surgut, 628412 (Russia), e-mail: botirov-nepi@mail.ru

${ }^{2}$ Institute of Plant Chemistry of them. Acad. SY Yunusov, Uzbek Academy of Sciences, ul. Mirzo Ulugbeka, 77, Tashkent, 700170 (Uzbekistan)

The review of materials research coumarins, flavonoids and lignans five species of the genus Haplophyllum (family Rutaceae) is carried out. It is found that each studied species of plants produces coumarins certain structural type and qualitative and quantitative composition coumarin varies depending on the ecological and geographical, soil and climatic conditions, as well as the growing season and plant organ. The study revealed some structural peculiarities and methods for establishing the structure and detection of coumarins on TLC. A possible scheme of biogenesis coumarins $H$. obtusifolium Ledeb was proposed. Based on the analysis of the data and taking into account the scheme for the biogenesis of coumarins obtusin, obtusifol and tusifolidiol proposed alternative structure.

Keywords: Haplophyllum A. Juss., coumarins, flavonoids and lignans, biogenesis, structure.

\footnotetext{
* Corresponding author.
} 


\section{References}

1. Willis J.C. A Dictionary of the flowering plants and ferns. Seventh edition. Cambridge, 1966, 519 p.

2. Rod Haplophyllum. Opisanie taksona. [Genus Haplophyllum. Description taxon] [Electronic resource]. URL: http://www.plantarium.ru/page/view/item/44438.html (in Russ.).

3. Rastitel'nye resursy SSSR: Cvetkovye rastenija, ih himicheskij sostav, ispol'zovanie. Semejstva RutaceaeElaeagnaceae. [Plant resources of the USSR: Flowering plants, their chemical composition and utilization. Family Rutaceae-Elaeagnaceae]. Leningrad, 1988. Pp. 10-15. (in Russ.).

4. Halmatov H.H. Dikorastushhie lekarstvennye rastenija Uzbekistana. [Wild medicinal plants of Uzbekistan]. Tashkent, 1964. 134 p. (in Russ.).

5. Markova L.P., Belenovskaja L.M., Nadezhina T.P., Sinickij B.C. Dikorastushhie poleznye rastenija flory Mongol'skoj narodnoj respubliki. [Wild useful plants flora Mongolian People's Republic]. Leningrad, 1985. Pp. 78-79. (in Russ.).

6. Bessonova I.A., Junusov S.Ju. Himija prirodnyh soedinenij, 1977, no. 3, pp. 303-324. (in Russ.).

7. Kholid S.A., Waterman P.G. Planta Med. 1981, vol. 43, pp. 148-152.

8. Ulubelen A., Öztürk M. Rec. Nat. Prod. 2008, vol. 2, no. 3, pp. 54-69.

9. Abyshev A.Z., Gashimov N.F. Himija prirodnyh soedinenij, 1979, no. 3, pp. 401-403. (in Russ.).

10. Abyshev A.Z., Gashimov N.F. Himija prirodnyh soedinenij, 1979, no. 3, pp. 403-404. (in Russ.).

11. Abyshev A.Z., Gashimov N.F. Himija prirodnyh soedinenij, 1979, no. 6, p. 845. (in Russ.).

12. Gashimov N.F., Abyshev A.Z., Kagramanov A.A., Rozhkova L.I. Chemistry of Natural Compounds, 1979, vol. 15, no. 1, p. 71.

13. Parhoodeh P., Rahmani M., Mohd Hashim N., Sukari M.A., Gwendoline E., Lian Ch. Molecules, 2011, vol. 16, pp. 2268-2273.

14. Batirov E.Kh., Matkarimov A.D., Batsuren D., Malikov V.M. Proc. first Inter. conf. Chem. and biotechnol. biol. active natur. prod. Varna, 1981, vol. 3(1), pp. 120-123

15. Vdovin A.D., Batsurjen D., Batirov Je.H., Jagudaev M.R., Malikov V.M. Himija prirodnyh soedinenij, 1983, no. 4, pp. 441-445. (in Russ.)

16. Matkarimov A.D. Izuchenie kumarinov Haplophyllum obtusifolium Ledeb: avtoref. dis. kand. him. nauk. [The study of coumarin Haplophyllum obtusifolium Ledeb: dis. Cand. Chem. Sci]. Tashkent, 1985, 23 p. (in Russ.).

17. Juldashev M.P. Kumarinovye i flavonolovye glikozidy Haplophyllum perforatum (M.V.) Kar et Kir. i Ferula varia (Schrenk) Trautv.: avtoref. dis. kand. him. nauk. [Coumarin glycosides and flavonolovye Haplophyllum perforatum (MV) Kar et Kir. and Ferula varia (Schrenk) Trautv.: dis. Cand. Chem. Sci]. Tashkent, 1988, 21 p. (in Russ.).

18. Batsurjen D., Batirov Je.H., Malikov V.M., Jagudaev M.R. Himija prirodnyh soedinenij, 1983, no. 2, pp. $142-147$. (in Russ.).

19. Bessonova I.A., Batirov Je.H., Jagudaev M.R. Himija prirodnyh soedinenij, 1988, no. 2, pp. 187-189. (in Russ.).

20. Batirov Je.H., Juldashev M.P., Malikov V.M. Himija prirodnyh soedinenij, 1990, no. 5, pp. 577-592. (in Russ.).

21. Abyshev A.Z., Zmejkov V.P., Sidorova I.P. Himija prirodnyh soedinenij, 1983, no. 3, pp. 301-306. (in Russ.).

22. Juichi M., Takemura Y., Okano M., Fukamiya N., Ito Ch., Furukawa H. Heterocycles, 1991, vol. 32, pp. 1189-1191.

23. Breitmaier E.W. Voelter ${ }^{13}$ C NMR spectroscopy. New York: Verlag Chem., 1978, 912 p.

24. Ahluwalia V.K., Khanna M., Singh R.P. Monatsh. Chem. 1982, vol. 113, pp. 197-200.

25. Grey A.L., Waterman P.G. Coumarins in the Rutaceae. // Phytochemistry. 1978. Vol. 17. Pp. 845-864.

26. Murray R.D.H, Mendez J., Brown S.A. The natural coumarins. New York, 1982, 648 p.

27. Murray R.D.H. Natur. Prod. Reports. 1989, vol. 6, pp. 591-624.

28. Brown S.A., March R.E., Rivett D.E.A., Thompson H.J. Phytochemistry. 1988, vol. 27, pp.391-395

29. Matkarimov A.D. Batirov Je.H., Malikov V.M., Sejtmuratov E. Himija prirodnyh soedinenij, 1982, no. 2, pp. $173-176$. (in Russ.).

30. Debenedetti S.L., Nadinic E.L., Coussio J.D., De Kimpe N., Dupon J.F., Declercq J.P. Phytochemistry. 1991, vol. 30, no. 8, pp. 2757-2758.

31. Batirov Je.H., Malikov V.M. Himija prirodnyh soedinenij, 1980, no. 3, pp. 330-334. (in Russ.).

32. Batirov Je.H. Malikov V.M., Mirzamatov R.T. Himija prirodnyh soedinenij, 1980, no. 4, p. 836. (in Russ.)

33. Batirov Je.H., Malikov V. M., Perel'son M.E. Himija prirodnyh soedinenij, 1981, no. 3, pp. 304-307. (in Russ.).

34. Juldashev M.P., Batirov Je.H., Malikov V.M. Himija prirodnyh soedinenij, 1985, no. 2, pp. 192-196. (in Russ.).

35. Juldashev M.P., Batirov Je.H., Malikov V.M. Himija prirodnyh soedinenij, 1985, no. 2, p. 269. (in Russ.).

36. Batirov Je.H., Juldashev M.P., Hushbaktova Z.A., Syrov V.N., Malikov V.M. Himija prirodnyh soedinenij, 1987, no. 1, pp. 66-70. (in Russ.)

37. Harborne J.B. Phytochemistry, 1981, vol. 20, pp. 1117-1119.

38. Anastas P.T., Stevenson R. J. Nat. Prod. 1991, vol. 54, no. 6, pp. 1687-1691.

39. Aminov S.D., Vahabov A.A., Sultanov M.B. Medicinskij zhurnal Uzbekistana, 1982, no. 6, pp. 52-54. (in Russ.).

40. Aminov S.D., Vahabov A.A. Doklady AN UzSSR, 1985, no. 8, pp. 44-45. (in Russ.).

41. Hushbaktova Z.A., Syrov V.N., Batirov Je.H. Himiko-farmacevticheskij zhurnal, 1991, vol. 25, no. 4, pp. 53-57. (in Russ.).

42. Juldashev M.P., Batirov Je.H., Babekov A.U., Jusupova S.M., Mamathonov A.U. Nauka, obrazovanie, tehnika, 1999, no. 2, pp. 84-86. (in Russ.).

43. Gonzalez A.G., Darvis V., Alonso G. Planta Med. 1979, vol. 36, pp. 200-203.

44. Inamori Y., Kubo M., Tsujibo H. et all. Chem. Pharm. Bull. 1986, vol. 34, pp. 3928-3932.

45. Ten L.N., Stepanichenko N.N., Muhamedzhanov S.Z., Aslanov H.A. Himija prirodnyh soedinenij, 1987, no. 5, pp. 772-773. (in Russ.) 